\section{Utfordringer ved genetisk veiledning av pakistansknorske familier}

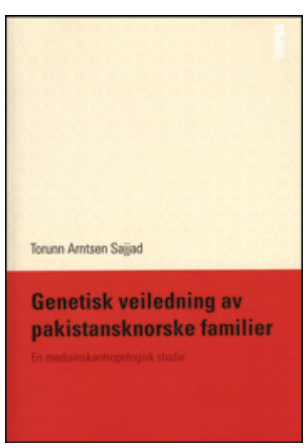

Torunn Arntsen Sajjad

Genetisk veiledning

av pakistansknorske familier

En medisinskantropologisk studie. 400 sider.

Oslo: Unipub, 2012. Pris NOK 398

ISBN 978-82-7477-564-0

Mens han var statsminister ble Kjell Magne Bondevik tilbudt et glass vin til maten under en festmiddag i Pakistan. Han takket høflig nei. Kelneren ble meget overrasket og utbrøt: «But, sir, are you not a christian?». Opptrinnet illustrerer at kulturforståelse er vanskelig og at stereotypier er utbredte.

Derfor er bøker som denne av sosialantropolog Torunn Arntsen Sajjad viktige for å spre kunnskap om slike temaer, som forståelse av genetiske sykdommer blant norskpakistanere. Boken er en omarbeidet versjon av hennes avhandling fra 2011 - Hvis det fødes et sykt barn, hva tror du det skyldes? En medisinskantropologisk studie av genetisk veiledning blant pakistansknorske familier - og er basert på en kvalitativ undersøkelse blant familier i Oslo som har vært til genetisk veiledning når de har født, eller har risiko for å få barn med alvorlige genetiske sykdommer. Hun har intervjuet familiene og legene som utførte veiledningen, og var også observatør under konsultasjoner.

Boken er skrevet og utformet som en vitenskapelig undersøkelse og er inndelt i ni kapitler som omhandler ulike aspekter av problemstillingen. Hennes hovedanliggende er å belyse asymmetrien i maktforholdet mellom de norske legene og de pakistanske familiene, som ofte har lite utdanning og til dels mystiske oppfatninger om arvelighet og reproduksjon. Forfatteren gir eksempler på hvordan familiene forklarer hvorfor de er «rammet av» syke barn: straff fra Gud for tabubrudd, at mor har grått under svangerskapet, at en sjalu svigerinne har kastet en forbannelse over den gravide.

Hennes fremstilling er detaljert og preget av engasjement, men blir noen ganger vel ordrik og gjentakende. Når hun er normativ i sin fremstilling, ligger hennes sympati hos familiene, som hun mener ofte blir overkjørt og misforstått av norske leger. Man kan få inntrykk av at hun mener at den ene sykdomsforklaringen er like mye verdt som den andre, uansett om den er basert på manglende kunnskap, religiøsitet eller overtro. Boken er interessant, selv om man ikke trenger å være enig i alle hennes vurderinger. Den er også en god påminnelse om at kommunikasjon er vanskelig - enten pasienten er norsk eller pakistansk.

Boken vil være av spesiell interesse for helsepersonell som jobber med pediatri og genetisk veiledning, men burde også være interessant for leger flest.

\section{Ingvild Heier}

Overlege, Barneklinikken

Oslo universitetssykehus, Ullevål

\section{Oversiktlig innføringsverk i prehospital traumatologi}

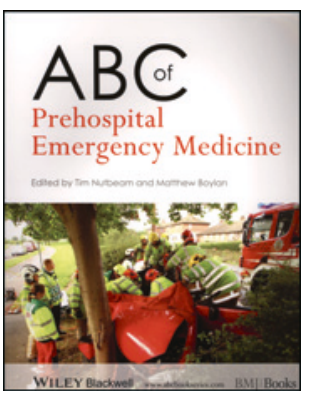

Tim Nutbeam, Matthew Boylan, red. $A B C$ of prehospital emergency medicine 215 s, tab, ill. Chichester: Wiley-Blackwell, 2013. Pris GBP 26

ISBN 978-0-470-65488-0

I den klassiske rekken av $A B C$-bøkene har det kommet enda et skudd på stammen. Denne boken omhandler den prehospitale fasen for den akutte pasienten og er en blanding av en lettlest oversikt og en tyngre klassisk tekstbok.

Inndelingen med 38 kapitler er god og oversiktlig, med en logisk oppbygging, hvor forfatterne begynner med introduksjonskapitler, fortsetter med ABCDE-systemet og spesifikke (primært) traumatiske sykdommer for så å avslutte med kapitler om forberedelse til katastrofehåndtering, «clinical governance» og forskning.

Forfatterlisten preges av en del tungvektere innenfor den anglosaksiske, prehospitale verdenen. Mange kapitler er preget av dette og inneholder ikke-evidensbaserte rutiner og retningslinjer som ikke er vanlig i Skandinavia. Tiltak som «skin to scoop» er ikke gjennomførbart i det skandinaviske klimaet - og heller ikke nødvendig. Likeledes kan det overraske at et generelt velskrevet kapittel om prehospital luftveishåndtering, hvor hovedparten av forfatterne er skandinaviske, erfarne prehospitalleger, nevner konsekvent bruk av «bougie»»» som vanlig og standard - dette er ikke tilfellet.

Teksten er utpreget traumeorientert og mangler nesten fullstendig søkelys på den prehospitale medisinske pasienten, som utgjør hoveddelen av den prehospitale pasientpopulasjonen. Når det er sagt, må jeg nevne at gjennomgangen av traumatologien er moderne og bra.

Illustrasjonene er rikholdige og nyttige, og både kapitteloversikt og stikkordregister er forbilledlige, hvilket gjør boken rask og enkel å bruke for å tilegne seg oversikt over enkelte emner.

Boken er en god og effektiv oversikt over prehospital medisin som jeg kan anbefale for alle som ønsker en innføring i emnet. Generelt må jeg likevel erkjenne at boken ikke legger opp til det nivå som forventes av en norsk luftambulansestandard.

Per P. Bredmose

Overlege, Luftambulanseavdelingen

Oslo universitetssykehus 